\title{
PERFORMANCE OF FILTERS COMPOSED OF BANANA STALK IN SWINE WASTEWATER TREATMENT ${ }^{1}$
}

\author{
RODRIGO JUNIOR NANDORF ${ }^{2}$, PAOLA ALFONSA VIEIRA LO MONACO ${ }^{2 *}$, ISMAIL RAMALHO HADDADE ${ }^{2}$, \\ LARISSA IONARA SILVA PAULA ${ }^{2}$, PAOLA HONORATO SALLA ${ }^{2}$, GUSTAVO HADDAD SOUZA VIEIRA ${ }^{2}$
}

\begin{abstract}
Using organic filters produced in local communities with low financial cost can reduce the environmental impacts caused by the disposal of untreated wastewater into receiving water bodies. In this study, the objective was to evaluate the efficiency of the filtration of swine wastewater (SWW) using banana stalk as an alternative material in an organic filter. SWW was applied to the organic filter and the filtered volume was converted into pore volume. Analyses of total solids, turbidity, color, total phosphorus, and total nitrogen were performed in the filter feed solution and effluent to evaluate treatment efficiency. Regression analyses were used to obtain equations in the estimation of the filtration performance in removing these variables from wastewater, with pore volume as an independent variable. The banana stalk filter did not remove total solids and color from the feed solution applied. Removal of 10-50\% of SWW turbidity were obtained by the banana stalk. Banana stalk was highly efficient in removing nitrogen and phosphorus from SWW, reaching mean removals of $67 \%$ and $62 \%$, respectively. In general, a banana stalk filter can be considered a promising alternative in the primary treatment of SWW.
\end{abstract}

Keywords: Organic filter. Agricultural waste. Effluent treatment.

\section{DESEMPENHO DE FILTROS CONSTITUÍDOS DE ENGAÇO DE BANANEIRA NO TRATAMENTO DE ÁGUAS RESIDUÁRIAS DA SUINOCULTURA}

\begin{abstract}
RESUMO - A utilização de filtros orgânicos produzidos em comunidades locais e com baixo custo financeiro pode proporcionar redução nos impactos ambientais ocasionados pelo lançamento de águas residuárias, sem tratamento, em cursos hídricos receptores. Neste estudo, objetivou-se avaliar a eficiência do processo de filtração de águas residuárias da suinocultura (ARS), utilizando engaço de bananeira como material alternativo em filtro orgânico. A ARS foi aplicada ao filtro orgânico,sendo o volume filtrado convertido em volume de poros. Análises de sólidos totais, turbidez, cor, fósforo total e nitrogênio total foram realizadas no afluente e efluente do filtro para a avaliação da eficiência de tratamento. Análises de regressão foram utilizadas para obtenção de equações na estimativa do desempenho da filtragem na remoção das referidas variáveis da água residuária, tendo-se como variável independente o volume de poros. $\mathrm{O}$ filtro de engaço de bananeira não proporcionou a remoção dos sólidos totais e da cor do afluente nele aplicado. Remoções de 10 a $50 \%$ da turbidez da ARS foram obtidas pelo engaço de bananeira. O engaço de bananeira proporcionou elevada eficiência na remoção de nitrogênio e fósforo da ARS, alcançando-se remoções médias de 67 e $62 \%$, respectivamente. De um modo geral, o filtro de engaço de bananeira pode ser considerado uma alternativa promissora no tratamento primário de águas residuárias de suinocultura.
\end{abstract}

Palavras-chave: Filtro orgânico. Resíduos agrícolas. Tratamento de efluentes.

\footnotetext{
${ }^{*}$ Corresponding author

${ }^{1}$ Received for publication in $06 / 04 / 2020$; accepted in $11 / 09 / 2020$.

Paper extracted from the undergraduate final project of the first author.

${ }^{2}$ Instituto Federal do Espírito Santo, Santa Teresa, ES, Brazil; rodrigojrnandorf@gmail.com - ORCID: 0000-0001-8771-9816, paolalomonaco2004@yahoo.com.br - ORCID: 0000-0001-5498-7451, ihaddade@gmail.com - ORCID: 0000-0003-0303-8808, larissaionarasilvapaula@gmail.com - ORCID: 0000-0003-1017-9422, paola.hsalla@gmail.com - ORCID: 0000-0002-6060-2906, ghsvieira@gmail.com - ORCID: 0000-0001-9963-1571.
} 


\section{INTRODUCTION}

Swine farming has great importance in the social and economic development of Brazil. It generates jobs and income for producers, making small rural properties viable. However, this activity may lead to serious environmental problems if the wastes generated are not properly managed (LIMA et al., 2019).

Swine wastewater (SWW), when discharged without treatment into water bodies, causes several environmental impacts. Due to the excess of nitrogen and phosphorus, swine manure can cause problems of eutrophication of surface waters, causing loss of biodiversity, water contamination, and waterborne diseases (SEGANFREDO, 2007; AMORIM et al., 2015). Matos, Freitas and Lo Monaco (2010) emphasize that, in addition to surface and groundwater pollution, inappropriate application of these wastes to soil can lead to salinization, pollution, and structure damage.

As the Brazilian environmental legislation established standards for effluent discharge into water bodies, these wastewaters need to be treated if this is the final destination option. If the option is to use these wastewaters in fertigation and the application is carried out in a localized manner, a preliminary and primary treatment needs to be performed in order to reduce the risks of emitter clogging (LO MONACO et al., 2009).

There are several processes for effluent treatment and/or use, which mostly are highly efficient, however, they require large investments. On the other hand, small family farmers, as is the case of most farms in the Espírito Santo state, Brazil, have low financial resources and a low technological level to employ sophisticated methods in the treatment of waste generated on their properties (OZA et al., 2019).

Among the simple and low cost solutions for wastewater treatment, filtration using organic materials stands out. According to Lo Monaco et al. (2014), organic waste from agricultural activities can be a good option for use as an alternative filtering medium to sand, due to its abundance, low cost of acquisition and also, because of the possibility of being composted after being discarded from the filters and subsequently used as agricultural fertilizer. In addition, the constituents of agricultural wastes are composed of lignin, cellulose, and hemicellulose, which have functional groups capable of forming compounds with metal ions in solution, while the small pores of the material can retain sedimentable and suspended particles (GUPTA; SUHAS, 2009). For these reasons, some wastes used as organic filters have been evaluated, such as sugarcane bagasse (LO MONACO; MATOS; BRANDÃO, 2011; OLIVEIRA; PINHEIRO; CAMPOS, 2017), wood sawdust (MATOS; MAGALHÃES; SARMENTO, 2010), ground corncob (LO MONACO; MATOS; BRANDÃO, 2011), coffee peel (BRANDÃO et al., 2003), coconut fiber (LO MONACO et al., 2009), Gliricidia branches (FRANCISCO et al., 2014), eucalyptus leaves (FRANCISCO et al., 2014), and bamboo leaves (FRANCISCO et al., 2014), as well as coffee grain parchment (MATOS; MAGALHÃES; FUKUNAGA, 2006; LO MONACO et al., 2011).

One of the wastes generated in large amounts in banana-producing regions is the banana stalk. Banana stalk, a structure that supports the banana bunch, is usually discarded after the fruits are harvested, whether in packaging boxes or in distribution centers. When disposed of inappropriately, it can contribute to generating phytosanitary problems and cause various environmental impacts. Thus, it becomes fundamental to provide a more noble and harmonic destination for this waste.

In this context, banana stalk may be an interesting material as a filtering medium in wastewater treatment, as it has a mass of fibers in its composition similar to that of coconut fibers, which have already been tested by Lo Monaco et al. (2009), who obtained high removal of total suspended solids, total solids, and total volatile solids. Thus, the use of banana stalk as a filtering material is believed to be a promising alternative in the primary treatment of wastewater, making both activities, swine farming and banana growing, sustainable. The objective of this study was to evaluate the efficiency of SWW filtration using banana stalk as an alternative material in an organic filter.

\section{MATERIAL AND METHODS}

The experiment was conducted in the experimental area and in the Laboratory of Water and Solid Waste Quality of the Federal Institute of Espírito Santo (IFES)-Campus Santa Teresa, ES, Brazil, at the following geographical coordinates: latitude $19^{\circ} 48^{\prime} 13^{\prime}$ ' S, longitude $40^{\circ} 40^{\prime} 42^{\prime}$ ' W, and average altitude of $127 \mathrm{~m}$.

The SWW used in the tests was collected in a reservoir, in the Swine Farming Sector of IFES Campus Santa Teresa, in Santa Teresa, ES. Table 1 shows the mean values of the physical and chemical constituents of the raw SWW.

The low values of turbidity, color, total solids, nitrogen, and phosphorus obtained in SWW, when compared with other authors (CAOVILLA et al., 2010; PACHECO et al., 2017; LIMA et al., 2019), are explained by scraping the manure before washing the bays, which considerably decreases the organic load and nutrients in the generated effluent.

The experimental workbench for SWW treatment consisted of a water tank, with a capacity of $500 \mathrm{~L}$, positioned $3 \mathrm{~m}$ above the filtration system. 
Table 1. Mean values of physical and chemical constituents of raw swine wastewater.

\begin{tabular}{cccccc}
\hline Turbidity & Color & $\mathrm{pH}$ & $\mathrm{TS}$ & $\mathrm{TN}$ & $\mathrm{TP}$ \\
\hline NTU & $\mathrm{mg} \mathrm{Pt} \mathrm{L}^{-1}$ & & $----------\mathrm{mg} \mathrm{L}^{-1}---------$ \\
147.0 & 645.0 & 7.2 & 120.2 & 396.7 & 16.3 \\
\hline
\end{tabular}

Where, $\mathrm{pH}$ - hydrogen potential; TS - total solids; TN - total nitrogen; and $\mathrm{TP}$ - total phosphorus.

The filtration system consisted of three 250mm-diameter polyvinyl chloride (PVC) pipes, with a cross sectional area of $490.87 \mathrm{~cm}^{2}$ and height of 0.8 $\mathrm{m}$, with valves installed at the bottom to enable outflow of the filtered effluent.

As a filtering material, banana stalk, Musa spp., obtained from small farms of the central mountainous region of Espírito Santo state was used. The material was crushed in a forage shredder machine, in order to obtain particles with a diameter between $2-3 \mathrm{~mm}$, as recommended by Lo Monaco et al. (2004). Then, the material was air dried for one week.

The filtering material was gradually placed in the filter, in 10-cm-thick layers, under compression of $12,490 \mathrm{~N} \mathrm{~m}^{-2}$ (pressure equivalent to that caused by a $70 \mathrm{~kg} \mathrm{man}$ ), until reaching a height of $0.6 \mathrm{~m}$, in a wooden cylinder of $2 \mathrm{~kg}$ and approximately $3 \mathrm{~cm}$ in diameter.

After adding the waste (banana stalk) up to the proposed height in the filter, the process of saturation with wastewater began. After saturation, the valve installed at the bottom of the filter was opened and from this point, the filtration process was continuous, keeping a hydraulic load of $0.20-0.25 \mathrm{~m}$ of wastewater above the surface of the filtering material.

By knowing the total volume of the filter occupied by the mass of filtering material and the drainable porosity obtained in the laboratory, it was possible to calculate the pore volume of the filter, that is, the volume of empty spaces in the filtering material, using Equation 1:

$$
P V=\left(P_{d} \times T V\right)
$$

where,

$P V$ - pore volume $\left(\mathrm{cm}^{3}\right)$;

$T V$ - total volume of the filtering layer $\left(\mathrm{cm}^{3}\right)$; and $P_{\mathrm{d}}-$ porosity of the column material $\left(\mathrm{cm}^{3} \mathrm{~cm}^{-3}\right)$.

A total volume of approximately $160 \mathrm{~L}$ of SWW was filtered, which corresponded to seven pore volumes, collected in2L PET bottles. Each pore volume corresponded to $23 \mathrm{~L}$. Thus, the samples were collected between filtration of $22.5 \mathrm{~L}$ and that of $23.5 \mathrm{~L}$ to obtain a sample relative to this number of pores.

The analyses of filter feed solution and effluent were performed at the Water Quality Laboratory of IFES, Campus of Santa Teresa, according to the recommendations proposed by Matos (2015). The variables evaluated and the methods and devices used in the laboratory analyses are described in Table 2.

Table 2. Constituents evaluated and the respective methods used for analysis.

\begin{tabular}{ll}
\hline Constituents & Method/Device \\
\hline Turbidity & Benchtop turbidimeter \\
Color & Colorimeter \\
Total Solids (TS) & Gravimetric \\
Total Nitrogen (TN) & Semi-micro Kjeldahl \\
Total Phosphorus (TP) & Spectrophotometry \\
\hline
\end{tabular}

After converting the effluent volume of the organic filters into pore volumes (Equation 1), curves were obtained associating the pore volume with the relative concentration of these variables, i.e. the relationship between the output concentrations (effluent) and the input concentrations (feed solution).
Regression analyses were used to obtain equations in the estimation ofthe filtration performance in removing the studied variables from wastewater, with pore volume as an independent variable. The models were chosen based on their overall significance ( $\mathrm{P}$ value), as well as the lower values of the Akaike Information Criteria and 
Bayesian Information Criteria in their significance ( $\mathrm{P}$ value) for the regression coefficients, using thet-test and adopting the 5\% probability level for type I error.In addition, the chosen model was the one with the highest coefficient of determination $\left(\mathrm{R}^{2}\right)$ for the variable under study. In each of the proposed regression models, the variables were evaluated for assumptions of homogeneity of variances (Koenker's and Breusch-Pagan Tests), normality (QQ-plot and Shapiro-Wilk test), and independence (DurbinWatson Test). The statistical procedures were performed usingthe"car", "lmtest", and "moments" packages of the Rstudio (R DEVELOPMENT CORE TEAM, 2019) software.

(a)

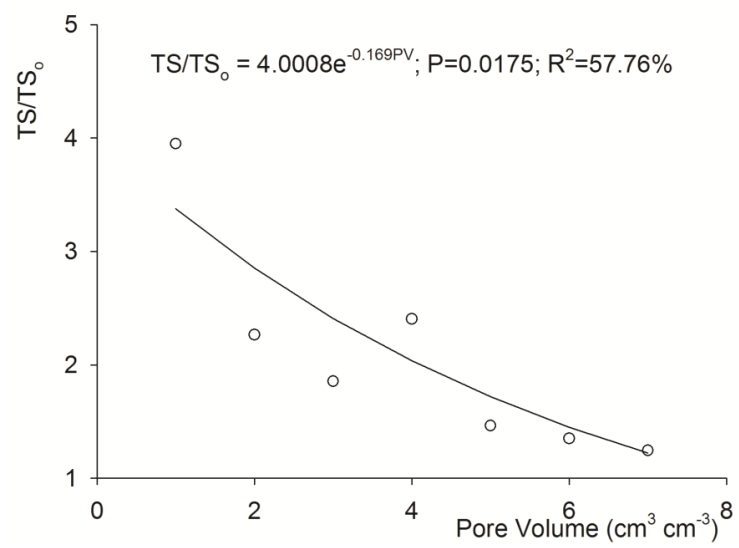

\section{RESULTS AND DISCUSSION}

The relative concentration of the variables expresses the relationship between output concentration (effluent) and input concentration (feed solution). Therefore, a relative concentration value greater than one means that the effluent contains a higher concentration than that of the feed solution. Thus, it was observed that there were decreasing exponential model adjustments of the relative concentrations of total solids (Figure 1a) and color (Figure 1c), and linear decreasing of the relative turbidity concentration (Figure 1b), as a function of the pore volume.

(b)

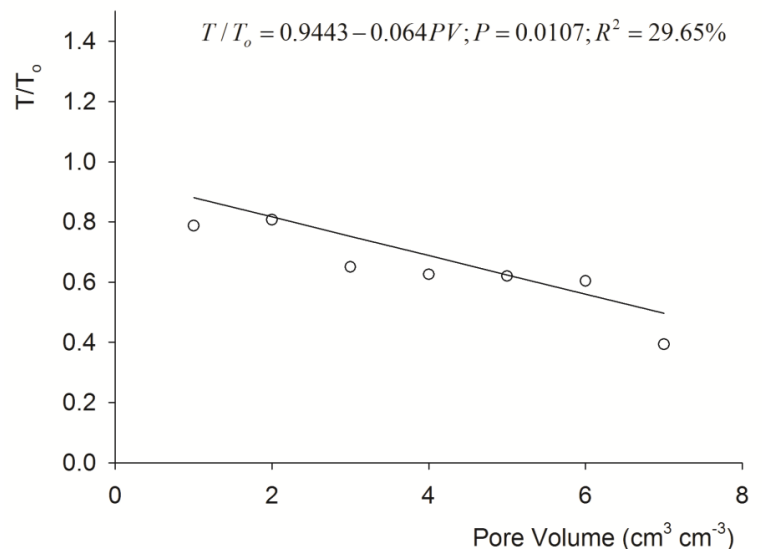

(c)

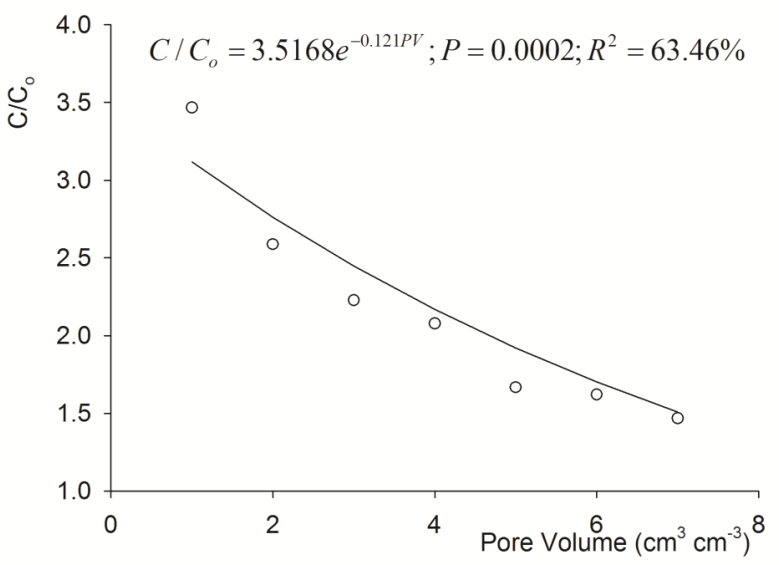

Figure 1. Mean values of relative concentrations of (a) total solids $\left(\mathrm{TS}_{\mathrm{TS}}\right)$, (b) turbidity $\left(\mathrm{T} / \mathrm{T}_{0}\right)$, and (c) color $\left(\mathrm{C} / \mathrm{C}_{0}\right)$, as a function of pore volume.

Even obtaining a decreasing exponential adjustment model, the filtering process was not efficient in removing total solids as a function of the pore volume, since the values of relative concentration remained higher than one until the end of filtration (Figure 1a). These results may have occurred because there was a large contribution of dissolved solids from the filtering material itself to the wastewater under treatment, as also verified by Lo Monaco et al. (2014), using wood sawdust as a filtering material in the treatment of sanitary sewage, and by Oliveira, Pinheiro and Campos (2017) in the 
initial filtered volumes, using sugarcane bagasse in the treatment of SWW. Opposite results have been found by other authors with other filtering materials in the treatment of SWW, as in the cases of coconut fiber (LO MONACO et al., 2009), chopped sugarcane bagasse, and ground corn cob (LO MONACO; MATOS; BRANDÃO, 2011), all of which led to removals greater than $40 \%$ of total solids. Francisco et al. (2014) obtained removals between $35-44 \%$ using filtering materials such as fine coal, Gliricidia branches, eucalyptus leaves, wood sawdust, and bamboo leaves in the treatment of cattle wastewater. However, before being subjected to filtration, the wastewater underwent a coagulation process using Moringa oleifera Lam.

The banana stalk promoted an efficiency of $10-50 \%$ in the removal of turbidity $\left(\mathrm{T} / \mathrm{T}_{0}=0.9\right.$ to $0.5)$, being described by a decreasing linear equation as a function of the pore volume filtered (Figure 1b). These results can be considered satisfactory and similar to those obtained by other authors in studies with organic filters (MAGALHÃES et al., 2005, 2006a; LO MONACO et al., 2009, 2011, 2014).

Removing turbidity from wastewater is extremely important, as this water quality parameter is related to the presence of suspended solids (VON SPERLING, 2011). If the effluent is discharged into water bodies without any treatment, the presence of suspended solids may reduce light penetration and compromise photosynthesis by algae and consequently, the production of oxygen in the water body. On the other hand, if the effluent is used in the fertigation of crops through localized irrigation systems, the previous removal of suspended solids becomes necessary in order to avoid clogging problems in drippers or micro-sprinklers. Thus, the banana stalk filter may be an interesting alternative to treat wastewater for destinations in both situations, whether for discharge into water bodies or in fertigation via localized irrigation systems.

Color removal in wastewater is important because this water quality parameter is related to the presence of dissolved solids (VON SPERLING, 2011). In regard to the color variable (Figure 1c), as observed for total solids, there was no removal by the banana stalk since the values of relative concentration remained higher than one until the end of the filtration. Since the banana stalk has pigments such as tannins and flavonoids (ONYEMA et al., 2016), the increase of color in the effluent from the filter is justified by the solubilization of the dissolved solids from the filtering material itself to the wastewater under treatment during the filtration process. This fact was evident in the visual observation of an increase in the color of the effluent compared to the feed solution. It was also noted that these pigments were released at a higher concentration in the first pore volume, gradually decreasing up to the seventh pore volume.

If the effluent is to be discharged into water bodies, the removal of $\mathrm{N}$-total and P-total from the wastewater becomes fundamental, since these are the elements that most contribute to eutrophication, causing several environmental impacts. No mathematical model fitted to the results obtained for total phosphorus (Figure 2a) and total nitrogen (Figure 2b), so only the mean values with their respective standard deviations are presented.

(b)

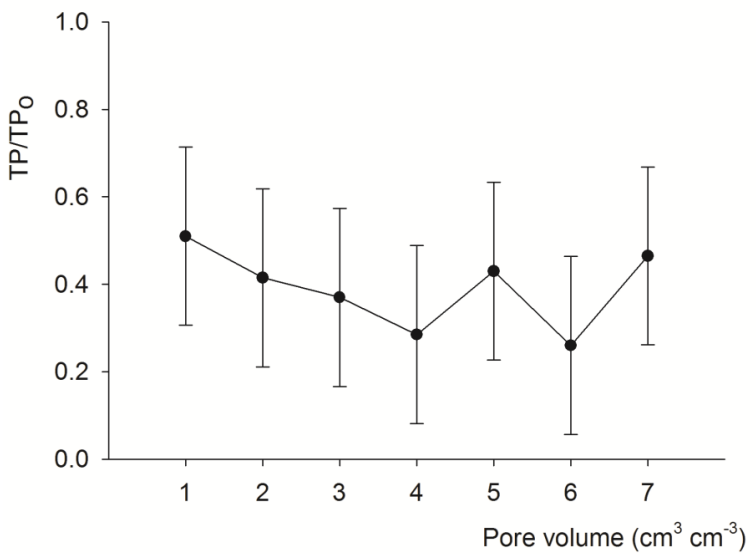

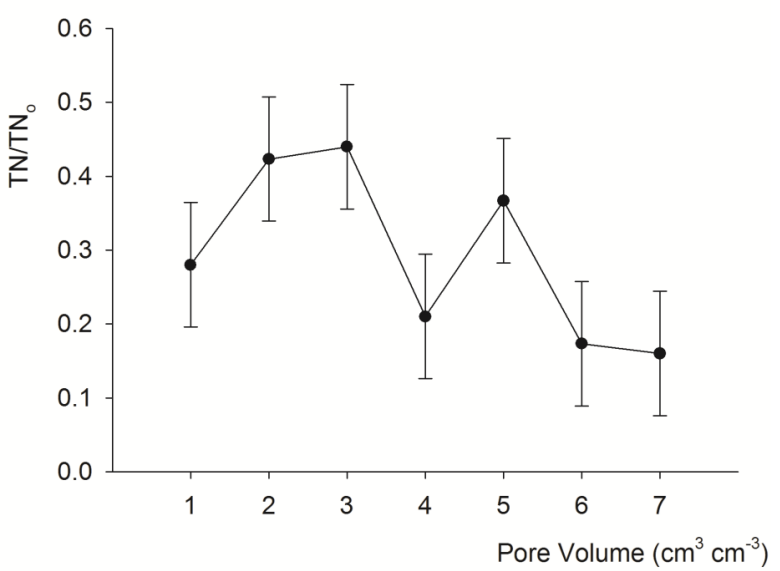

Figure 2. Mean values of relative concentrations of (a) total phosphorus $\left(\mathrm{TP} / \mathrm{TP}_{0}\right)$ and (b) total nitrogen $\left(\mathrm{TN} / \mathrm{TN}_{0}\right)$, as a function of pore volume.

In the case of total phosphorus (Figure 2a), the mean values of removal were between $50 \%(\mathrm{TP} /$ $\left.\mathrm{TP}_{0}=0.5\right)$ and $75 \%\left(\mathrm{TP} / \mathrm{TP}_{0}=0.25\right)$, obtaining an average of $62.5 \%$. These removals can be considered excellent given the absence of any treatment either before or after the filter. The results obtained in this study confirm the high efficiency in phosphorus removal by organic filters, since they were similar to 
those obtained by other authors (LO MONACO et al., 2004, 2009; LO MONACO; MATOS; BRANDÃO, 2011), who verified removals between $58-70 \%$ in organic filters in the treatment of SWW.

Banana stalk promoted nitrogen removal around $55 \%\left(\mathrm{TN} / \mathrm{TN}_{0}=0.45\right)$ to $85 \%\left(\mathrm{TN} / \mathrm{TN}_{0}=\right.$ $0.15)$, which corresponds to an average removal of $70 \%$ (Figure $2 \mathrm{~b}$ ). Similar to phosphorus, the results for nitrogen removal by banana stalk can be considered excellent when compared to those of other organic filtering materials in the treatment of SWW. For instance, Lo Monaco, Matos and Brandão (2011) obtained maximum removals of $45 \%$ and $50 \%$ with ground corn cob and sugarcane bagasse, respectively, and Lo Monaco et al. (2009) obtained average removals around $30 \%$ using coconut fiber.

According to Lo Monaco et al. (2009) and Lo Monaco, Matos and Brandão (2011), phosphorus and nitrogen, contrary to what occurs with potassium and sodium, are strongly associated with the organic material. Thus, the authors concluded that the retention of solid material can somehow explain the obtained results for removal in relation to total phosphorus. Thus, the greater the removal of total solids from the SWW feed solution, the greater the removal of total nitrogen and total phosphorus.

In this study, there was no removal of total solids (Figure 1a), but there was a high removal of nitrogen and phosphorus by the filtering material, contrasting the association made by Lo Monaco et al. (2009) and Lo Monaco, Matos and Brandão (2011). Thus, it is believed that, in this case, the mineral forms of phosphorus and nitrogen were retained more efficiently and in greater proportions, due to the adsorption of these elements to the exchange sites existing in the mass of the filtering material.

Even with the high efficiency in removing nitrogen and phosphorus, the effluent still contained these nutrients that can be retained and used in a treatment/disposal subsequent to the filter before being released into water bodies. It is suggested that the effluent of the organic filter be treated/disposed in treatment systems that use vegetation to absorb these elements, such as fertigation, runoff ramps, or constructed wetland systems.

In general, the banana stalk filter can be considered a promising alternative in the primary treatment of SWW. Once the filtering capacity of the banana stalk has been superseded, when there is a gradual clogging of its pores followed by low flow rates of the liquid under treatment (MATOS; MAGALHÃES; SARMENTO, 2010), it will be necessary to replace the filter material (total or partial) at defined time intervals. According to Febrer (2000) and Magalhães et al. (2006b), these changes can be relatively frequent, depending on the rate applied and the concentration of solids present in the wastewater.

The higher operating cost of the system, due to the need to periodically replace the filters, can be offset by the production of organic fertilizers (FEBRER, 2000), since, after being discarded, the banana stalk must be submitted to composting and later used as agricultural fertilizer.

\section{CONCLUSION}

According to the results obtained, it is concluded that the banana stalk filter did not remove total solids and color from the feed solution applied. Removals of $10 \%$ to $50 \%$ of SWW turbidity were obtained with the banana stalk. Banana stalk was highly efficient in removing nitrogen and phosphorus from the SWW, reaching mean removals of $70 \%$ and $62.5 \%$, respectively. In general, the banana stalk filter can be considered a promising alternative in the primary treatment of SWW, making small rural properties viable.

\section{ACKNOWLEDGMENTS}

The authors thank FAPES and PRODIF for the financial assistance and IFES - Campus of Santa Teresa for the infrastructure to conduct this research study.

\section{REFERENCES}

AMORIM, F. et al. Unidades combinadas RAFASAC para tratamento de água residuária de suinocultura - parte II nutrientes. Engenharia Agrícola, 35: 931-940, 2015.

BRANDÃO, V. S. et al. Retenção de poluentes em filtros orgânicos operando com águas residuárias da suinocultura. Revista Brasileira de Engenharia Agrícola e Ambiental, 7: 329-334, 2003.

CAOVILLA, F. A. et al. Características químicas de solo cultivado com soja e irrigado com água residuária da suinocultura. Revista Brasileira de Engenharia Agrícola e Ambiental, 14: 692-697, 2010 .

FEBRER, M. C. A. Aproveitamento agrícola de material orgânico utilizado como filtro no tratamento de águas residuárias da suinocultura. 2000. 130 f. Dissertação (Mestrado em Engenharia Agrícola: Área de Concentração em Manejo e tratamento de resíduos) - Universidade Federal de Viçosa, Viçosa, 2000.

FRANCISCO, J. P. et al. Desempenho de filtros orgânicos com o uso de extrato de sementes de Moringa oleifera LAM. Irriga, 19: 705-713, 2014. 
GUPTA, V. K.; SUHAS. Application of low-cost adsorbents for dye removal - A review. Journal of Environmental Management, 90: 2313-2342, 2009.

LIMA, C. J. C. S. et al. Soil changes and yield of maize fertilized with swine wastewater. Revista Caatinga, 32: 167-178, 2019.

LO MONACO, P. A. V. et al. Desempenho de filtros constituídos por fibras de coco no tratamento de águas residuárias de suinocultura. Revista Engenharia na Agricultura, 17: 473-480, 2009.

LO MONACO, P. A. V. et al. Desempenho de filtros constituídos por pergaminho de grãos de café (Coffea sp.) no tratamento de águas residuárias. Coffe Science, 6: 120-127, 2011.

LO MONACO, P. A. et al. Influência da granulometria da serragem de madeira como material filtrante no tratamento de águas residuárias.

Revista Brasileira de Engenharia Agrícola e Ambiental, 8: 116-119, 2004.

LO MONACO, P. A. V. et al. Tratamento de esgoto sanitário utilizando coagulante natural seguido de filtro orgânico. Revista Caatinga, 27: 28-40, 2014.

LO MONACO, P. A. V.; MATOS, A. T.; BRANDÃO, V. S. Influência da granulometria dos sólidos triturados de sabugo de milho e bagaço de cana-de-açúcarcomo materiais filtrantes no tratamento de águas residuárias da suinocultura. Engenharia Agrícola, 31: 975-985, 2011.

MAGALHÃES, M. A. et al. Influência da compressãono desempenho de filtrosorgânicos para tratamentode águas residuárias da suinocultura. Revista Engenharia na Agricultura, 13: 26-32, 2005.

MAGALHÃES, M. A. et al. Operação de filtros orgânicos utilizados no tratamento de águas residuárias da suinocultura. Revista Brasileira de Engenharia Agrícola e Ambiental, 10: 472-478, 2006a.

MAGalhãeS, M. A. et al. Compostagem de bagaço de cana-de-açúcar triturado utilizado como material filtrante de águas residuárias da suinocultura. Revista Brasileira de Engenharia Agrícola e Ambiental, 10: 466-471, $2006 \mathrm{~b}$.

MATOS, A. T. Manual de análise de resíduos sólidos e águas residuárias. 1. ed. Viçosa, MG: UFV, 2015. 149 p.
MATOS, A. T.; MAGALHÃES, M. A.; FUKUNAGA, D. C. Remoção de sólidos em suspensão na água residuária da despolpa de frutos do cafeeiro em filtros constituídos por pergaminho de grãos de café submetido a compressões. Engenharia Agrícola, 26: 610-616, 2006.

MATOS, A. T.; FREITAS, W. S.; LO MONACO, P. A. V. Eficiência de alagados construídos na remoção de poluentes de águas residuárias da suinocultura. Ambi-Água, 5: 119-132, 2010.

MATOS, A. T.; MAGAlHÃES, M. A. SARMENTO, A. P. Perda de carga em filtros orgânicos utilizados no tratamento de água residuária de suinocultura. Revista Engenharia Agrícola, 30: $527-537,2010$

OLIVEIRA, A. P. S.; PINHEIRO, E. F. M.; CAMPOS, D. V. B. Avaliação do tratamento da água residuária da suinocultura utilizando filtro orgânico constituído de bagaço de cana-de-açúcar. Revista Virtual de Química, 9: 1970-1984, 2017.

ONYEMA, C. T. et al. Phytochemical and antimicrobial analysis of banana pseudo stem (Musa acuminata). British Journal of Pharmaceutical Research, 10: 1-9, 2016.

OZA, E. F. et al. Treatment of swine wastewater using anaerobic filters with different types of support media. Bioscience Journal, 35: 561-569, 2019.

PACHECO F. P. et al. Physical attributes of soil after swine wastewater application as cover fertilizer on maize crop and black oats sequence. Revista Caatinga, 30: 955-962, 2017.

R DEVELOPMENT CORE TEAM. R: A language and environment for statistical computing. $\mathrm{R}$ Foundation for Statistical Computing, Vienna, Austria, 2019. Disponível em: <https://www.rproject.org/>. Acesso em: 03 Dez. 2019.

SEGANFREDO, M. A. A gestão ambiental na suinocultura. 1. ed. Brasília, DF: Embrapa Suínos e Aves, 2007. 302 p.

VON SPERLING, M. Introdução à Qualidade das Águas e ao Tratamento de Esgotos (Princípios do Tratamento Biológico de Águas Residuárias). vol. 1, 4. ed Belo Horizonte, MG: DESA-UFMG, 2011. 452 p. 